\title{
Illegitimate wage practices in Eastern Europe: The case of "envelope wages""
}

\author{
Colin. C. Williams ${ }^{* *}$
}

To evaluate the prevalence in Eastern Europe of a little discussed illegitimate wage practice in which employers pay their formal employees both a declared wage and an undeclared 'envelope wage', an extensive survey involving 10,671 face-to-face interviews in eleven post-socialist societies is here reported. The finding is that 10 per cent of all employees received envelope wages during the last 12 months amounting on average to two-fifths of their gross annual wage. Revealing how although unevenly distributed, this wage practice is nonetheless ubiquitous throughout Eastern Europe, the paper concludes by briefly reviewing policy options for tackling this labour arrangement.

Der Beitrag untersucht die wenig erforschte illegale Praxis in Osteuropa, wonach Arbeitgeber ihren Mitarbeitern sowohl einen deklarierten Lohn als auch einen undeklarierten, sog. 'Briefumschlag-Lohn' bezahlen. Dazu wurde eine umfangreiche Umfrage mit 10.671 persönlichen Interviews in elf postsozialistischen Ländern durchgeführt. Das Ergebinis ist, dass 10 Prozent aller Angestellten während der letzten 12 Monate 'Briefumschlag-Löhne' empfingen, was im Durchschnitt zwei Fünftel ihres Jahreslohns umfasste. Es wird aufgezeigt, dass diese Praxis zwar ungleich verbreitet, aber doch überall in Osteuropa anzutreffen ist. Zum Abschluss werden einige politische Handlungsoptionen angesprochen, die geeignet sind, diese Praktiken zu bekämpfen.

Key words: envelope wages; informal economy; shadow sector; tax compliance; undeclared work; Eastern Europe.

* $\quad$ Manuscript received: 10.06.08, accepted: 23.07 .08 (1 revision)

** Colin C. Williams, Prof., School of Management, University of Sheffield. Main research areas: Re-theorising the nature of economic development and investigating the implication for public policy. Corresponding address: c.c williams@sheffield ac.uk. 


\section{Introduction}

Over the past decade, a small tributary of scholarly thought analysing the postsocialist societies of Eastern Europe has begun to unravel a little discussed wage practice used by formal employers. This is the labour arrangement where employers pay their formal employees two wages, an official wage which is declared to the state for tax and social security purposes and an unofficial 'envelope' wage which is not declared and allows employers to avoid paying their full social insurance and tax liabilities (Karpuskiene 2007; Neef 2002; Sedlenieks 2003; Žabko/Rajevska 2007; Williams 2007; Williams/Round 2007). Until now, whether this violation of work payment principles by formal employers is ubiquitous across the Eastern European labour market or merely exists in a few small enclaves has not been evaluated. This paper seeks to fill this gap.

To do this, the paper commences by showing that although there is a small emergent literature on envelope wages in Eastern Europe, most of the studies so far conducted have been local and small-scale. The result is a lack of understanding of its overall prevalence, nature and distribution in Eastern Europe. To resolve this, the second section introduces a cross-national survey conducted in 2007. In this paper, the data collected from the 10,671 face-to-face interviews in eleven Eastern European nations on envelope wage practices are reported. Analysing these findings, the third section will reveal that a significant minority of formal employees in Eastern Europe receive envelope wages and that even if it is more common in some countries, types of business and population groups than others, it is a ubiquitous practice. The final section then briefly addresses the various policy options for tackling this wage practice in Eastern Europe.

\section{A review of previous literature on envelope wages}

A large body of literature now exists on informal employment in both Eastern Europe (Neef 2002; Pavlovskaya 2004; Round/Williams 2008; Smith/Stenning 2006; Wallace/Haerpfer 2002; Wallace/Latcheva 2006; Williams 2007; Williams/Round 2007-2008) and beyond (Arrowsmith et al. 2003; Bajada/Schneider 2005; European Industrial Relations Observatory 2005; Fernandez-Kelly/Shefner 2006; Gilman et al. 2002; Kirchler 2007; Ram et al. 2002a/b 2003; Schneider 2008; Williams 2006). Very little of this literature, however, has analysed the issue of envelope wages. This is because a recurring assumption is that formal and informal employment is separate and discrete; formal employees working for formal employers, according to this dualistic way of thinking, cannot be engaged in informal working practices. The consequence is that few have enquired into whether waged employment can be concurrently both and therefore the realm of envelope wages. 
An emergent stream of literature examining Eastern Europe, however, has started to recognise how an employment relationship can be both formal and informal and drawn attention to the wage practice where formal employees receive from their formal employer two wages, an official wage declared to the state for tax and social security purposes and an unofficial 'envelope' wage which is not declared (Karpuskiene 2007; Neef 2002; Sedlenieks 2003; Žabko/Rajevska 2007; Williams 2007; Williams/Round 2007). Paying envelope wages not only allows employers to avoid paying their full social insurance and tax liabilities but also to encourage employees no longer wanted to voluntarily leave so that they do not incur any social costs in terms of redundancy pay (Hazans 2005; Round et al. 2008).

Previous studies of envelope wages have tended to be small-scale qualitative studies in specific Eastern European nations, such as Latvia (OECD 2003; Sedlenieks 2003; Žabko/Rajevska 2007), Lithuania (Karpuskiene 2007; Woolfson 2007), Romania (Neef 2002), Russia (Williams/Round 2007) and Ukraine (Round et al. 2008; Williams 2007). For instance, the study in Lithuania by Woolfson (2007) is an in-depth case study of one person, albeit a cause celebre, whilst the Latvian study by Sedlenieks (2003) reports 15 face-to-face interviews conducted in Riga. Although the Ukraine survey covers 600 households, it is limited to three localities (Williams 2007), whilst the evidence from Russia is based on interviews with 313 households in three districts of Moscow (Williams/Round 2007). None are national-level representative sample surveys.

Despite this, such studies provide a strong rationale for further investigation of this practice. Some 30 per cent of employees in Ukraine reported receiving envelope wages (Williams 2007), whilst in Moscow some two-thirds (65 per cent) received envelope wages ranging from 20 to 80 per cent of their total gross wage packet (Williams/Round 2007). Comparing labour force and employer surveys, meanwhile, the OECD (2003) find that 20 per cent of private sector employees in Latvia earn envelope wages. What remains unknown, however, is whether this is a ubiquitous practice or confined to a few small pockets of the Eastern European labour market. Consequently, in 2007, a survey was undertaken to more fully understand its extent, nature and distribution across Eastern Europe.

\section{Methodology: studying envelope wages in Eastern Europe}

Is it common for employees in Eastern Europe to be paid an additional undeclared ('envelope') wage by their formal employers? If so, where is it common and amongst whom? And are such wages paid for overtime or for regular hours worked? To answer these questions, a 2007 survey is here reported whose origins lie in late 2005 when the European Commission funded a team (which included this paper's author) to design a questionnaire to investigate 
undeclared work in the EU (TNS Infratest et al. 2006). This was subsequently implemented as Special Eurobarometer No. 284 ('Undeclared work in the European Union'), as part of wave 67.3 of Eurobarometer.

The current paper reports its findings in relation to envelope wage payments, the subject matter of one section of the questionnaire, in Eastern European economies. Replicating the sampling method of other Eurobarometer surveys, 10,671 face-to-face interviews were conducted in the 11 Eastern European countries that are European Union (EU) member states, namely Bulgaria, Czech Republic the former East Germany, Estonia, Hungary, Latvia, Lithuania, Poland, Slovakia, Slovenia and Romania. In each nation, national marketing agencies were employed to implement a multi-stage random (probability) sampling method to select 1,000 respondents (500 in the former East Germany). For each country, a number of sampling points were drawn with probability proportional to population size (for total coverage of the country) and to population density according to the Eurostats NUTS II (or equivalent) and the distribution of the resident population in terms of metropolitan, urban and rural areas. In each of these selected sampling units, a starting address was then randomly drawn. Further addresses (every nth address) were then selected using standard 'random route' procedures from the initial address. This is the standard sampling methodology employed in all Eurobarometer surveys in EU member states.

Once households had been selected, interviews were carried out face-to-face in people's homes and in the appropriate national language with adults aged 15 years and over. Given the sensitivity of the topic, the decision was taken at an early stage that face-to-face interviews would be necessary rather than telephone interviews, mail-shot questionnaires and so forth. In each selected household, the respondent was chosen at random (following the 'closest birthday rule'). During the interview, the responses were collected and collated using CAPI (computer assisted personal interview) in countries where this was available.

For all countries, a national weighting procedure was then used for analytical purposes employing marginal and intercellular weighting by comparing the sample with the universe description taken from Eurostat population data and national statistical offices. In each nation, this weighting procedure ensured that the gender, age, region and size of locality of the sample were proportionate to the universe. The resultant weighted data were then analysed using the Statistical Package for Social Scientists (SPSS) which allows not only for basic descriptive statistics to be produced but also, if desired, more complex multivariant and probit modelling.

All results discussed below are the weighted results. Nevertheless, they remain estimates and should be treated with caution. Their accuracy, everything being equal, rests upon the sample size and upon the observed percentage. With samples of 1,000 interviews, the real percentages differ within the confidence limits detailed in Table 1. This needs to be taken into account when interpreting 
the results. It must also be realised that direct survey results in previous studies of undeclared work have generally produced lower levels of participation in such work than more indirect survey methods using proxy indicators (Bajada/Schneider 2005; Williams/Windebank 1998) and as such, the estimates below should perhaps be treated conservatively as lower-bound estimates of the extent of envelope wage practices in Eastern Europe.

Table 1. Confidence limits of the observed percentages in the survey

\begin{tabular}{|l|l|}
\hline Observed percentages & Confidence limits \\
\hline $10 \%$ or $90 \%$ & +or -1.9 points \\
\hline $20 \%$ or $80 \%$ & + or -2.5 points \\
\hline $30 \%$ or $70 \%$ & +or -2.7 points \\
\hline $40 \%$ or $60 \%$ & + or -3.0 points \\
\hline $50 \%$ & + or -3.1 points \\
\hline
\end{tabular}

To collect these data, and given that the issue of undeclared work and envelope wages is a sensitive survey topic, the interview schedule commenced with introductory attitudinal questions about undeclared work, then questions about the goods and services that they had purchased on an undeclared basis, followed by questions on whether they had been paid envelope wages and finally, whether they had supplied undeclared work. Given the focus of this paper on envelope wages, discussion here is confined to this issue. Firstly, respondents were asked, 'Sometimes employers prefer to pay all or part of the regular salary or the remuneration for extra work or overtime hour's cash-in-hand and without declaring it to tax or social security authorities. Did your employer pay you all or part of your income in the last 12 months in this way?'. Secondly, interviewees were asked 'Was this income part of the remuneration for your regular work, was it payments for overtime, or both?' and thirdly, they were asked what percentage of their gross yearly income from their main job is received as an envelope wage. To analyse employees' attitudes towards envelope wages finally, interviewees were asked whether they were happy receiving an envelope wage or whether they would have preferred to have their total salary declared.

Before reporting the results, however, the reliability of the findings need to be briefly addressed. It is sometimes argued, especially by adherents to indirect proxy indicators, that respondents are unlikely to respond honestly to interviewers when discussing illegitimate work practices. Such a criticism has been refuted many times (Williams 2006). Just because the remuneration is hidden from or unregistered by the state for tax and social security purposes does not mean that people will hide it from each other or even academic researchers. In this survey, similar conclusions were reached. In 88 per cent of the interviews conducted, interviewers reported good or excellent cooperation on the part of the respondent. In only 2 per cent of cases was cooperation 
deemed to be bad. Even if such remuneration is hidden from the state, therefore, it appears to be very much hidden in plain sight so far as researchers and the wider population are concerned. In consequence, given the sensitivity of the issue under investigation, the pilot nature of the survey and the low number of respondents reporting participation, it is important that the findings should be treated with caution. However, even if the results reported below should be perhaps conservatively treated as lower-bound estimates of the prevalence of envelope wages in the EU, there remains little reason to doubt their overall reliability and validity.

\section{An evaluation of envelope wages in Eastern Europe}

Of the 10,671 face-to-face interviews in the 11 Eastern European economies, some 5,280 were with employees. Some 1 in 10 of these employees (488 employees in total) had received envelope wages from their employer during the previous 12 months. On average, these amounted to two-fifths (42 per cent) of their total wage, although this was higher for the 40 per cent receiving envelope wages for their regular work and lower for the 20 per cent receiving it for extra work or overtime. Who are these employees in receipt of envelope wages? Is this practice confined to a few pockets of the Eastern European labour market or is it more ubiquitous? To answer these questions, firstly, the cross-national variations, secondly, the variations across different types of business and population group and third and finally, the attitudes of employees receiving envelope wages are evaluated.

\section{A cross-national comparison of envelope wages}

As Table 2 displays, although employees reported receiving envelope wages in all 11 countries surveyed, the prevalence and character of envelope wages displays marked cross-national variations. Whilst just 3 per cent of employees in the Czech Republic and the former East Germany and 5 per cent in Slovenia had received envelope wages in the previous 12 months, in Romania this figure was 23 per cent, 17 per cent in Latvia, 14 per cent in Bulgaria and 11 per cent in both Poland and Lithuania.

Analysing the share of gross income received as an envelope wage, this increases as the commonality of this practice grows in societies. In Romania where nearly a quarter of all employees ( 23 per cent) receive envelope wages, employees receive on average some 70 per cent of their wage in this manner whilst in nations in which lower portions of the labour force receive envelope wages, a smaller share of their total wage is received on a cash-in-hand basis.

Similarly, in countries where a high share of the labour force receive envelope wages (Romania, Latvia, Bulgaria, Lithuania and Poland) and some half of their total wage is on average accumulated in this manner, envelope wages are more 
often paid for regular work. In contrast, in nations where a lower share of the labour force receive envelope wages (Czech Republic, Slovenia, Slovakia, Hungary and Estonia), and employees receive a smaller portion of their total wage 'under-the-table', envelope wages are more usually paid for overtime or extra work.

Table 2. \% of employees in employment receiving envelope wages in the past 12 months, by nation (Base: $n=5,280$ )

\begin{tabular}{|c|c|c|c|c|c|c|c|}
\hline \multirow[t]{2}{*}{ Country } & \multirow{2}{*}{$\begin{array}{c}\text { No. of } \\
\text { waged } \\
\text { employees } \\
\text { surveyed }\end{array}$} & \multirow[b]{2}{*}{$\begin{array}{l}\% \text { all } \\
\text { employees } \\
\text { receiving } \\
\text { envelope } \\
\text { wages }\end{array}$} & \multirow[b]{2}{*}{$\begin{array}{c}\% \text { of } \\
\text { gross } \\
\text { income } \\
\text { received } \\
\text { as } \\
\text { envelope } \\
\text { wages }\end{array}$} & \multicolumn{4}{|c|}{ Envelope wages paid for: } \\
\hline & & & & $\begin{array}{l}\text { Regula } \\
\text { r work }\end{array}$ & $\begin{array}{l}\text { Overtime/ } \\
\text { extra } \\
\text { work }\end{array}$ & $\begin{array}{l}\text { Both } \\
\text { regular } \\
\& \\
\text { overtime } \\
\text { work }\end{array}$ & $\begin{array}{l}\text { Refusal } \\
+ \text { don't } \\
\text { know }\end{array}$ \\
\hline Romania & 453 & 23 & 70 & 48 & 9 & 41 & 2 \\
\hline Latvia & 511 & 17 & 46 & 47 & 18 & 34 & 1 \\
\hline Bulgaria & 446 & 14 & 44 & 46 & 15 & 37 & 2 \\
\hline Lithuania & 446 & 11 & 48 & 44 & 10 & 46 & 0 \\
\hline Poland & 337 & 11 & 53 & 35 & 15 & 50 & 0 \\
\hline Estonia & 457 & 8 & 31 & 37 & 20 & 32 & 11 \\
\hline Hungary & 392 & 8 & 24 & 19 & 50 & 27 & 4 \\
\hline Slovakia & 537 & 7 & 25 & 39 & 43 & 18 & 0 \\
\hline Slovenia & 431 & 5 & 23 & 13 & 40 & 28 & 19 \\
\hline $\begin{array}{l}\text { Ex-East } \\
\text { Germany }\end{array}$ & 196 & 3 & 24 & 33 & 50 & 17 & 33 \\
\hline $\begin{array}{l}\text { Czech } \\
\text { Republic }\end{array}$ & 501 & 3 & 14 & 13 & 46 & 41 & 0 \\
\hline
\end{tabular}

Source: Eurobarometer survey 2007

The outcome is a polarisation of Eastern European economies. On the one hand, there are countries where envelope wages are extensive, paid to employees more for their regular hours and amount to on average around half of formal employees' wages and on the other hand, nations where envelope wages are less common, paid more for overtime or extra work and amount on average to around a quarter of employees' wage packets.

\section{Who pays and receives envelope wages?}

It is not just across nations that variations exist. Different types of businesses use envelope wages to varying extents and some population groups are more likely than others to receive envelope wage.

Commencing with who pays envelope wages, Table 3 reveals that smaller-sized businesses are more likely to pay envelope wages; one in five (19 per cent) employees in businesses with 1-20 employees receive envelope wages and this 
steadily decreases as firm size increases, with just 3 per cent of employees in larger businesses with over 500 employees receiving envelope wages. The result is that even though only 35 per cent of employees are in businesses with less than 20 employees in Eastern and Central European nations, 53 per cent of those receiving envelope wages are in such small businesses. These smaller businesses also pay on average a larger proportion of their employees' gross wages as an envelope wage.

Table 3. Extent and nature of envelope wages: by firm size and sector (Base: $n=5,280$ )

\begin{tabular}{|c|c|c|c|c|c|c|c|c|}
\hline \multirow[t]{2}{*}{ Weighted } & \multirow{2}{*}{$\begin{array}{c}\% \text { who } \\
\text { receive } \\
\text { envelope } \\
\text { wages }\end{array}$} & \multirow{2}{*}{$\begin{array}{c}\% \text { of } \\
\text { gross } \\
\text { wage } \\
\text { received } \\
\text { as } \\
\text { envelope } \\
\text { wage }\end{array}$} & \multirow{2}{*}{$\begin{array}{c}\% \text { of } \\
\text { total } \\
\text { receiving } \\
\text { an } \\
\text { envelope } \\
\text { wage }\end{array}$} & \multirow{2}{*}{$\begin{array}{l}\% \text { of } \\
\text { surveyed } \\
\text { population }\end{array}$} & \multicolumn{4}{|c|}{$\begin{array}{l}\text { Envelope wage paid as remuneration } \\
\text { for: }\end{array}$} \\
\hline & & & & & $\begin{array}{c}\text { Regular } \\
\text { work }\end{array}$ & $\begin{array}{l}\text { Over- } \\
\text { time/ } \\
\text { Extra } \\
\text { work }\end{array}$ & $\begin{array}{c}\text { Both } \\
\text { regular } \\
\& \\
\text { overtime } \\
\text { work }\end{array}$ & $\begin{array}{c}\text { Refusal } \\
+ \text { don't } \\
\text { know }\end{array}$ \\
\hline All & 10 & 42 & 100 & 100 & 40 & 20 & 37 & 3 \\
\hline \multicolumn{9}{|l|}{$\begin{array}{l}\text { No. of } \\
\text { employees } \\
\text { in business: }\end{array}$} \\
\hline $1-20$ & 19 & 43 & 53 & 35 & 37 & 23 & 39 & 1 \\
\hline $21-50$ & 12 & 43 & 20 & 20 & 46 & 16 & 32 & 6 \\
\hline $51-100$ & 13 & 35 & 13 & 12 & 56 & 19 & 21 & 4 \\
\hline $101-500$ & 7 & 39 & 11 & 19 & 48 & 25 & 23 & 4 \\
\hline $501+$ & 3 & 37 & 4 & 14 & 29 & 43 & 21 & 7 \\
\hline \multicolumn{9}{|l|}{ Sector: } \\
\hline $\begin{array}{l}\text { Construc- } \\
\text { tion }\end{array}$ & 20 & 52 & 15 & 25 & 46 & 11 & 42 & 1 \\
\hline Industry & 9 & 33 & 28 & 20 & 45 & 29 & 23 & 2 \\
\hline $\begin{array}{l}\text { Household } \\
\text { services }\end{array}$ & 3 & 40 & 4 & 1 & 50 & 0 & 50 & 0 \\
\hline Transport & 15 & 49 & 9 & 11 & 26 & 17 & 54 & 2 \\
\hline $\begin{array}{l}\text { Personal } \\
\text { services }\end{array}$ & 11 & 40 & 16 & 14 & 37 & 27 & 33 & 3 \\
\hline Retail & 11 & 33 & 12 & 11 & 36 & 32 & 30 & 2 \\
\hline $\begin{array}{l}\text { Repair } \\
\text { services }\end{array}$ & 18 & 33 & 5 & 7 & 23 & 23 & 48 & 6 \\
\hline $\begin{array}{l}\text { Hotel, } \\
\text { restaurant, } \\
\text { cafes }\end{array}$ & 13 & 27 & 6 & 6 & 44 & 16 & 24 & 16 \\
\hline Agriculture & 14 & 45 & 5 & 5 & 48 & 17 & 35 & 0 \\
\hline
\end{tabular}

Analysing the variations across sectors, meanwhile, this wage arrangement is disproportionately clustered in the construction sector where one in five employees (20 per cent) receive part of their remuneration in this manner and on average this amounts to over half ( 52 per cent) of their wage. Indeed, only 15 per cent of all employees surveyed worked in the construction industry but 25 
per cent of those paid envelope wages, with a relatively greater share (46 per cent) paid as remuneration for their regular work. It is not only the construction industry, however, where envelope wages are found. Some 18 per cent of employees in the repair services sector received envelope wages in the last 12 months, 15 per cent in the transport sector, 14 per cent in the agricultural sector, 13 per cent in the hotel and restaurant sector, 11 per cent in retail sector, 11 per cent working in personal services, 9 per cent in the manufacturing sector and 3 per cent in the household services sector. Envelope wages, therefore, are more prevalent in some businesses and sectors than others. However, there is no business type or sector where this practice is wholly absent.

Who, therefore, receives envelope wages? Examining its prevalence by occupation, Table 4 reveals that manual workers are more likely to receive envelope wages than white collar workers. Nevertheless, manual workers on average receive just 41 per cent of their gross pay as an envelope wage. This figure is higher for managers (who receive 47 per cent as an envelope wage). In major part, this is because they more commonly receive envelope wages for their regular work rather than for overtime or extra work.

Table 4 also reveals that men are more likely to receive envelope wages than women: 12 per cent of men in employment but just 7 per cent of women employees, meaning that over two-thirds (68 per cent) of those receiving envelope wages are men who are also more likely to receive an envelope wage as part of their regular wage, whilst women more commonly receive such a wage for overtime and/or extra work conducted.

Younger employees are also more likely to receive envelope wages. Some 13 per cent of employees aged less than 25 years old are paid envelope wages, but this steadily decreases with age to only 5 per cent among those aged 55 or more. Nevertheless, even if envelope wages are more highly concentrated amongst younger employees, the share of one's wage received off-the-books rises with age, with just 48 per cent of the gross wage of those aged 15-24 years old received as an envelope wage but 66 per cent of the gross wage of those over 54 years older. 
Table 4. Extent and nature of envelope wages: by population group (Base: $n=5,280)$

\begin{tabular}{|c|c|c|c|c|c|c|c|c|}
\hline \multirow[t]{2}{*}{ Weighted } & \multirow[b]{2}{*}{$\begin{array}{l}\text { \% who } \\
\text { receive } \\
\text { envelope } \\
\text { wages in } \\
\text { last } 12 \\
\text { months }\end{array}$} & \multirow[b]{2}{*}{$\begin{array}{c}\% \text { of } \\
\text { gross } \\
\text { wage } \\
\text { received } \\
\text { as } \\
\text { envelope } \\
\text { wage }\end{array}$} & \multirow{2}{*}{$\begin{array}{l}\% \text { of all } \\
\text { receiving } \\
\text { envelope } \\
\text { wage }\end{array}$} & \multirow{2}{*}{$\begin{array}{c}\% \text { of } \\
\text { surveyed } \\
\text { population }\end{array}$} & \multicolumn{4}{|c|}{ Envelope wage paid as remuneration for: } \\
\hline & & & & & $\begin{array}{l}\text { Regular } \\
\text { work }\end{array}$ & $\begin{array}{l}\text { Overtime } \\
\text { / } \\
\text { extra } \\
\text { work }\end{array}$ & $\begin{array}{l}\text { Both } \\
\text { regular } \\
\& \\
\text { overtime } \\
\text { work }\end{array}$ & $\begin{array}{l}\text { Refusal } \\
+ \text { don't } \\
\text { know }\end{array}$ \\
\hline \multicolumn{9}{|l|}{$\begin{array}{l}\text { General } \\
\text { Occupa-tion: }\end{array}$} \\
\hline Managers & 7 & 47 & 16 & 21 & 49 & 16 & 33 & 2 \\
\hline $\begin{array}{l}\text { Other white } \\
\text { collar } \\
\text { workers }\end{array}$ & 8 & 40 & 22 & 26 & 38 & 28 & 33 & 1 \\
\hline $\begin{array}{l}\text { Manual } \\
\text { workers }\end{array}$ & 11 & 41 & 62 & 53 & 38 & 19 & 39 & 4 \\
\hline \multicolumn{9}{|l|}{ Gender: } \\
\hline Man & 12 & 44 & 68 & 53 & 39 & 17 & 40 & 4 \\
\hline Woman & 7 & 26 & 32 & 47 & 41 & 26 & 30 & 3 \\
\hline \multicolumn{9}{|l|}{ Age: } \\
\hline $15-24$ & 13 & 48 & 15 & 11 & 32 & 29 & 38 & 1 \\
\hline $25-39$ & 10 & 40 & 46 & 42 & 43 & 19 & 36 & 2 \\
\hline $40-54$ & 9 & 44 & 34 & 37 & 40 & 18 & 36 & 6 \\
\hline $55+$ & 5 & 66 & 6 & 10 & 36 & 21 & 39 & 4 \\
\hline \multicolumn{9}{|l|}{$\begin{array}{l}\text { Education } \\
\text { (end of): }\end{array}$} \\
\hline 15 & 10 & 31 & 8 & 7 & 56 & 11 & 31 & 2 \\
\hline $16-19$ & 10 & 41 & 67 & 63 & 38 & 22 & 37 & 3 \\
\hline $20+$ & 8 & 45 & 25 & 30 & 42 & 20 & 36 & 2 \\
\hline \multicolumn{9}{|l|}{$\begin{array}{l}\text { Gross formal } \\
\text { job } \\
\text { income/mont } \\
h(€)\end{array}$} \\
\hline$<500$ & 13 & 38 & 61 & 54 & 40 & 24 & 33 & 3 \\
\hline $500-1000$ & 9 & 39 & 30 & 37 & 38 & 18 & 42 & 2 \\
\hline $1001-2000$ & 13 & 70 & 8 & 7 & 53 & 6 & 31 & 10 \\
\hline $2001-3000$ & 14 & 50 & 1 & 1 & 0 & 33 & 67 & 0 \\
\hline $3001+$ & 0 & 0 & 0 & 1 & 0 & 0 & 0 & 0 \\
\hline \multicolumn{9}{|l|}{$\begin{array}{l}\text { Hours/week } \\
\text { in formal } \\
\text { employment }\end{array}$} \\
\hline$<10$ & 17 & 27 & 2 & 1 & 75 & 0 & 25 & 0 \\
\hline $10-20$ & 9 & 40 & 2 & 2 & 44 & 22 & 33 & 0 \\
\hline $21-30$ & 8 & 43 & 3 & 4 & 25 & 25 & 50 & 0 \\
\hline $31-40$ & 8 & 37 & 50 & 63 & 42 & 17 & 35 & 6 \\
\hline $41+$ & 16 & 46 & 43 & 30 & 37 & 24 & 37 & 2 \\
\hline
\end{tabular}


Similarly, although those on low formal wages are more likely to receive envelope wages, it needs to be noted that such illegitimate payments prevail across all income groups. Analysing the hours worked per week, it is again the case that even if such envelope payments are more prevalent among those at the two ends of the spectrum, namely those employed less than 10 hours per week and those working over 41 hours per week, the vast majority receiving envelope wages (93 per cent) spend more than 30 hours per week in employment.

Table 5. Attitude towards envelope wages: by population group (Base: $n=5,280$ )

\begin{tabular}{|c|c|c|c|c|}
\hline & $\begin{array}{l}\text { Happy with } \\
\text { this }\end{array}$ & $\begin{array}{l}\text { Prefer full } \\
\text { declaration }\end{array}$ & It depends & $\begin{array}{l}\text { Don't know/ } \\
\text { refuse }\end{array}$ \\
\hline All & 39 & 33 & 17 & 11 \\
\hline \multicolumn{5}{|l|}{ By type of envelope wage: } \\
\hline $\begin{array}{l}\text { Part of remuneration for regular } \\
\text { work }\end{array}$ & 37 & 31 & 18 & 14 \\
\hline Overtime, extra work & 55 & 25 & 14 & 6 \\
\hline Both regular and overtime work & 33 & 38 & 18 & 11 \\
\hline \multicolumn{5}{|l|}{ Gender: } \\
\hline Man & 43 & 32 & 14 & 11 \\
\hline Woman & 30 & 34 & 23 & 13 \\
\hline \multicolumn{5}{|l|}{ Age: } \\
\hline $15-24$ & 53 & 26 & 15 & 6 \\
\hline $25-39$ & 39 & 35 & 16 & 10 \\
\hline $40-54$ & 34 & 34 & 18 & 14 \\
\hline $55+$ & 33 & 30 & 11 & 26 \\
\hline \multicolumn{5}{|l|}{ Occupation: } \\
\hline Managers & 29 & 35 & 19 & 17 \\
\hline Other white collar workers & 50 & 21 & 15 & 14 \\
\hline Manual workers & 38 & 36 & 17 & 9 \\
\hline \multicolumn{5}{|l|}{ Gross formal job income/month: } \\
\hline$<€ 500$ & 42 & 35 & 16 & 7 \\
\hline$€ 500-1000$ & 34 & 38 & 14 & 14 \\
\hline$€ 1001-2000$ & 31 & 25 & 22 & 22 \\
\hline$€ 2001-3000$ & 0 & 67 & 33 & 0 \\
\hline$€ 3001+$ & 0 & 0 & 0 & \\
\hline \multicolumn{5}{|l|}{ Hours/week in formal employment: } \\
\hline$<10$ & 75 & 13 & 0 & 12 \\
\hline $10-20$ & 36 & 36 & 9 & 19 \\
\hline $21-30$ & 33 & 33 & 8 & 26 \\
\hline $31-40$ & 39 & 33 & 16 & 12 \\
\hline $41+$ & 38 & 33 & 19 & 10 \\
\hline
\end{tabular}

Source: Eurobarometer survey 2007

Contrary to the political hyperbole currently surrounding the relationship between immigration and informal employment, meanwhile, this survey reveals 
that even if migrants might be the principal participants in wholly off-the-books work without contract (although this has never been shown to be the case), the vast bulk of those receiving envelope wages (98 per cent) were born in the country where they currently work.

\section{Employees' attitudes towards envelope wages}

Are those paid envelope wages happy with this arrangement? Given that they potentially receive higher wages than might be the case if employers had to deduct the tax and social insurance contributions, one might assume that employees would express contentment with this kind of payment. However, Table 5 reveals that just two in five ( 39 per cent) employees receiving envelope wages are happy to do so. A third (33 per cent) would prefer full declaration and the remaining 28 per cent are either undecided or refused to answer. Their attitude, nevertheless, largely depends on whether such payments are for regular hours worked or for overtime. Contentment was highest among those receiving such wages for extra work or overtime hours; 55 per cent are happy with this arrangement. Employees receiving envelope wages for their regular work, or for both their regular work and overtime hours, are less happy and would prefer full declaration.

As earlier studies in Russia and Ukraine reveal, this displeasure with envelope wage payments is in major part because when their official declared wage is lower than their actual wage, it prevents them accessing their full entitlement to social security and pension payments and constrains their ability to get credit, loans and mortgages (Williams 2007; Williams/Round 2007). Indeed, this dissatisfaction with receiving envelope wages, especially for regular work, clearly signals that the decision to pay off-the-books is not reached cooperatively and amicably between the employer and employee. It appears to be an arrangement imposed on employees by employers. Many employees, this survey reveals, would prefer to receive their regular salary (as well as overtime payments) on a declared basis but their employer obliges them to receive a portion as an envelope wage so that the employer can reduce the social contributions that they pay. Whether these savings are passed onto the employee or kept by the employer has not been evaluated in this survey. This could usefully be investigated in future more qualitative studies.

Employees' attitudes towards envelope wages, moreover, also vary across different population groups. Men, younger age groups, those earning lower formal wages and working low hours are more content receiving an envelope wage than other groups. However, this is largely because these groups are most likely to receive envelope wages for overtime or extra work rather than for their regular hours. 


\section{Implications for policy}

Given that one in ten employees in these 11 Eastern European countries receive envelope wages which on average amount to some two-fifths of their total wage, what can be done to tackle this wage practice?

A first policy option is to do nothing. A primary rationale for adopting such a laissez-faire approach towards envelope wages is that the level of formal employment might decrease if one eradicates this wage practice because of the increase in labour costs for employers of shifting work into the formal economy. Indeed, this is perhaps the major reason for Eastern European governments sometimes having ignored, overlooked or simply tacitly condoned envelope wage practices. The fear has been that if envelope wage practices are clamped down on, where at least the employees are officially registered and a portion of the earnings declared, employers will turn to wholly off-the-books work. Before accepting this justification for a laissez-faire approach, however, it is important to recognise the impacts of tacitly condoning this practice. Ignoring or overlooking the payment of envelope wages will not only result in employees being denied full access to social security payments, mortgages and loans but also the continuation of unfair competition between businesses (both on an intraand inter-national level) and a race to the bottom in terms of employment practices. The outcome will be to hinder the attainment of broader societal goals such as social inclusion by depriving the state of the revenue required to finance social protection. For these reasons, a laissez-faire approach towards envelope wages is here rejected. Instead, intervention is seen to be required to eradicate such a wage practice. However, what form should it take? And how can it be attentive to the possibility that employers always have the option of turning to wholly off-the-books employment if they do not wish to formalise their employment practices?

A first policy option is for the state to detect and punish 'bad' behaviour, namely employers paying envelope wages. Measures used by this 'negative reinforcement' approach might include improving detection of this wage arrangement, such as by enhancing the coordination of strategy and operations across government as well as data matching and sharing, and increasing the penalties for employers caught paying envelope wages so as to change the actual and perceived cost/benefit calculation confronting them. The problem is that evaluations in the broader sphere of informal employment are far from conclusive about the effectiveness of such an approach. Although some find that improving detection reduces non-compliance for some groups (Beron et al. 1992; Slemerod et al. 2001), others find that non-compliance grows (Bergman/Nevarez 2006; Varma/Doob 1998; Webley/Halstead 1986). Similarly, although some find that increasing penalties reduces non-compliance (De Juan et al. 1994; Klepper/Nagin 1989), others identify that it leads to its growth (Murphy 2005; Varma/Doob 1998; Webley/Halstead 1986). 
Given these largely inconclusive evaluations of punitive measures, another policy option is to pursue more enabling approaches that encourage and reward compliance rather than punish non-compliance (European Commission 2007; Kirchler 2007; Renooy et al. 2004; Small Business Council 2004; Williams 2006). To facilitate and reward 'good' behaviour (i.e., employers paying declared wages) rather than taking it as given, at least three different sets of policy measures can be used. Each is considered in turn.

Firstly, preventative measures might be pursued to stop from the outset employers considering the use of envelope wages. Measures might include: simplifying regulatory compliance such as the procedures required to both register and pay declared employees; shifting on a societal level from direct to indirect taxation systems, and raising the level of the minimum wage. In Eastern Europe, that is, minimum wage levels were largely set cautiously at around half the average wage level (European Commission 2007). The purported rationale was to prevent a shift from formal to informal employment. The problem, however, is that low minimum wages might prevent a shift into informal employment, but provides greater scope for paying a large portion of employees' earnings as an envelope wage. Raising the minimum wage closer to the average wage level would reduce the portion of the total wage paid as an envelope wage. The issue of course is that employers might decide to employ workers on a wholly informal basis if the minimum wage level is raised. This policy measure of increasing the minimum wage level will therefore need to be piloted and evaluated, especially with regard to determining whether there is a tipping point at which employers shift from formalising to informalising their workforce.

Secondly, there are more curative measures to help employers currently paying envelope wages to put their affairs in order. One example is to offer amnesties to employers deciding to fully declare the wages they pay. Another is to shift from the use of direct to indirect taxes, a proposal currently advocated by the European Commission (European Commission 2007), in order to reduce employer contributions and therefore the need for employers to seek savings by using envelope wage arrangements.

Third and finally, indirect rather than direct controls could be used to elicit behaviour change amongst employers. Reflecting the greater use of indirect controls (alongside direct controls) in organisations to enhance performance, one might envisage such commitment measures being scaled up and applied on a societal (rather than organisational) level in order to promote 'highcommitment' societies so far as tax morality is concerned. One policy initiative to win 'hearts and minds' is to provide tax education. Another is to raise awareness about the benefits of formal employment. A prominent example here is the awareness raising campaign pursued in Latvia about the benefits of declared work and disadvantages of envelope wages entitled 'work contracts 
work'. Although this particular initiative has not been so far evaluated, evidence from the UK reveals that such advertising campaigns extolling the benefits of declared work have had a return-cost ratio of 19:1 in terms of revenue returns for tax authorities (i.e., $£ 19$ return for every $£ 1$ spent) while punitive measures have a return-cost ratio of just 5:1 (National Audit Office 2008). The strong intimation is therefore that indirect controls could well be an effective policy instrument for tackling envelope wages.

In sum, policy options for tackling envelope wages range from punitive, through preventative and curative, to commitment measures. These policy instruments, however, are not mutually exclusive. A government for example, might increase the minimum wage and at the same time offer amnesties to employers putting their affairs in order by bringing envelope wage payments into the declared realm and then, for those who fail to comply, implement tougher sanctions for those subsequently caught whilst at the same time introducing campaigns to elicit greater commitment amongst employers and employees to tax morality.

\section{Conclusions}

Building upon a small stream of literature emerging out of Eastern Europe that highlights the existence of envelope wages, this paper has reported the first extensive survey of this wage arrangement in this region. Analysing data from 11 Eastern European economies, the finding is that 1 in 10 formal employees had received envelope wages in the previous 12 months and that these undeclared payments on average amounted to some two-fifths (42 per cent) of their gross wage. Such a wage practice, moreover, is ubiquitous in all sectors, occupations, firm sizes, countries and population groups throughout the EU, even if it is relatively more common in some rather than others.

The finding that this wage practice is not confined to a few small pockets of the Eastern European labour market but is widespread has significant implications. On the one hand, it displays that this labour practice needs to be brought out of the margins and positioned more centre-stage in economic analyses in Eastern Europe as well as for further in-depth evaluations to be conducted of how envelope wages operate in practice. However, it is not just a fuller understanding of how envelope wages are used in practice that is required. On the other hand, there is also a need for much greater discussion of how this waged practice might be tackled. Hopefully, this paper will stimulate such discussion of not only this so far largely neglected wage practice but also further evaluation and sharing of knowledge of how to tackle it. If it does so, then it will have achieved its objective. 


\section{Acknowledgements}

The author would like to thank the Employment Analysis division of DG Employment and Social Affairs at the European Commission for providing access to the database so that the analysis in this paper could be undertaken. The normal disclaimers of course apply.

\section{References}

Arrowsmith, J./Gilman, M./Edwards, P./Ram, M. (2003): The impact of the National Minimum Wage in small firms, in:British Journal of Industrial Relations, 41, 3, 435456.

Bajada, C./Schneider, F. (2005): Size, Causes and Consequences of the Underground Economy: an international perspective. Aldershot: Ashgate.

Bergman, M./Nevarez, A. (2006): Do audits enhance compliance? An empirical assessment of VAT enforcement, in: National Tax Journal, 59, 4, 817-832.

Beron, K.J./Tauchen, H.V./Witte, A.D. (1992): The effect of audits and socio-economic variables on compliance, in: Slemrod, J. (eds.): Why People Pay Taxes, Ann Arbor: University of Michigan Press, 67-89.

De Juan, A./Lasheras, M.A./Mayo, R. (1994): Voluntary tax compliant behavior of Spanish income taxpayers, in: Public Finance, 49, 1, 90-105.

European Commission (2007): Stepping up the fight against undeclared work. Brussels: European Commission.

European Industrial Relations Observatory (2008): Thematic issue: industrial relations and undeclared work, (http://eurofound.europa.eu/eiro/thematicfeature11.html (last accessed 15th June 2008).

Fernandez-Kelly, P. (2006): Introduction, in: Fernandez-Kelly, P./Shefner, J. (eds.). Out of the Shadows: political action and the informal economy in Latin America, Pennsylvania: Pennsylvania State University Press, 1-19.

Gilman, M./Edwards, P./Ram, M./Arrowsmith, J. (2002): Pay determination in small firms in the UK: the case of the national minimum wage, in: Industrial Relations Journal, 33, 1, 52-67.

Hazans, M. (2005): Latvia: working too hard?, in: Vaughan-Whitehead, D. (eds.): Working and Employment Conditions in the new EU member states: convergence or diversity? Geneva: ILO-EU, 161-212.

Karpuskiene, V. (2007): Undeclared work, tax evasion and avoidance in Lithuania. Paper presented at colloquium of the Belgian Federal Service for Social Security on Undeclared Work, Tax Evasion and Avoidance, Brussels, June.

Kirchler, E. (2007): The Economic Psychology of Tax Behaviour. Cambridge: Cambridge University Press.

Klepper, S./Nagin, D. (1989): Tax compliance and perceptions of the risks of detection and criminal prosecution, in: Law and Society Review, 23, 2, 209-240.

Murphy, K. (2005): Regulating more effectively: the relationship between procedural justice, legitimacy and tax non-compliance, in: Journal of Law and Society 32, 4, 562-589. 
National Audit Office (2008): Tackling the hidden economy. London: National Audit Office.

Neef, R. (2002): Aspects of the informal economy in a transforming country: the case of Romania, in: International Journal of Urban and Regional Research, 26, 2, 299-322.

OECD (2003): Labour Market and Social Policies in the Baltic Countries. Paris: OECD.

Pavlovskaya, M. (2004): Other transitions: multiple economies of Moscow households in the 1990s, in: Annals of the Association of American Geographers, 94, 2, 329-251.

Ram, M./Gilman, M./Arrowsmith, J./Edwards, P. (2003): Once more into the sunset? Asian clothing firms after the National Minimum Wage, in: Environment and Planning C: Government and Policy, 71, 3, 238-261.

Ram, M./Edwards, P./Jones, T. (2002a): Employers and illegal migrant workers in the clothing and restaurant sectors. London: DTI Central Unit Research.

Ram, M./Jones, T./Abbas, T./Sanghera, B. (2002b): Ethnic minority enterprise in its urban context: South Asian restaurants in Birmingham, in: International Journal of Urban and Regional Research, 26, 1, 24-40.

Renooy, P./Ivarsson, S./van der Wusten-Gritsai, O./Meijer, R. (2004): Undeclared Work in an Enlarged Union: an analysis of shadow work - an in-depth study of specific items. Brussels: European Commission.

Round, J./Williams, C.C. (2008): Everyday tactics and spaces of power: the role of informal economies in post-Soviet Ukraine, in: Social and Cultural Geography, 9, 2, 171-85.

Round, J./Williams, C.C./Rodgers, P. (2008): Corruption in the post-Soviet workplace: the experiences of recent graduates in contemporary Ukraine, Work, Employment and Society, 22, 1, 149-66.

Schneider, F. (2008): The Hidden Economy. Cheltenham: Edward Elgar.

Sedlenieks, K. (2003): Cash in an envelope: corruption and tax avoidance as an economic strategy in contemporary Riga, in: Arnstberg, K-O./Boren, T. (eds.) Everyday economy in Russia, Poland and Latvia. Stockholm: Almqvist and Wiksell, 25-69.

Slemrod, J./Blumenthal, M./Christian, C.W. (2001): Taxpayer response to an increased probability of audit: evidence from a controlled experiment in Minnesota, in: Journal of Public Economics, 79, 4, 455-483.

Small Business Council (2004): Small Business in the Informal Economy: making the transition to the formal economy. London: Small Business Council.

Smith, A./Stenning, A. (2006) Beyond household economies: articulations and spaces of economic practice in postsocialism, in: Progress in Human Geography, 30, 1, 1-14.

TNS Infratest, Rockwool Foundation and Regioplan (2006): Feasibility study on a direct survey about undeclared work VC/2005/0276. Brussels: Directorate General of Employment and Social Affairs, European Commission.

Varma, K.N./Doob, A.N. (1998): Deterring economic crimes: the case of tax evasion, in: Canadian Journal of Criminology, 40, 2, 165-84.

Wallace, C./Haerpfer, C. (2002): Patterns of participation in the informal economy in EastCentral Europe, in: Neef, R./Stanuclescu, M. (eds.) The Social Impact of Informal Economies in Eastern Europe. Aldershot: Ashgate. 
Wallace, C./Latcheva, R. (2006): Economic transformation outside the law: corruption, trust in public institutions and the informal economy in transition countries of Central and Eastern Europe, in: Europe-Asia Studies, 58, 1, 81-102.

Webley, P./Halstead, S. (1986): Tax evasion on the micro: significant stimulations per expedient experiments, in: Journal of Interdisciplinary Economics, 1, 1, 87-100.

Williams, C.C. (2008): A critical evaluation of public policy towards undeclared work in the European Union, in: Journal of European Integration, 30, 2, 273-290.

Williams, C.C. (2007): Tackling undeclared work in Europe: lessons from a study of Ukraine, in: European Journal of Industrial Relations, 13, 2, 219-237.

Williams, C.C. (2006): The Hidden Enterprise Culture: entrepreneurship in the underground economy. Cheltenham: Edward Elgar.

Williams, C.C./Round, J. (2007): Beyond negative depictions of informal employment: some lessons from Moscow, in: Urban Studies, 44, 12, 2321-2338.

Williams, C.C./Round, J. (2008): Re-theorising the nature of informal employment: some lessons from Ukraine, in: International Sociology, 23, 3, 367-388.

Williams, C.C./Windebank, J. (1998): Informal Employment in the Advanced Economies: implications for work and welfare, London: Routledge.

Woolfson, C. (2007): Pushing the envelope: the 'informalization' of labour in postcommunist new EU member states, in: Work, Employment and Society, 21, 3, 551564.

Žabko, M.A./Rajevska, F. (2007): Undeclared work and tax evasion: case of Latvia. Paper presented at colloquium of the Belgian Federal Service for Social Security on Undeclared Work, Tax Evasion and Avoidance. Brussels, June. 